\title{
Aborto de feto asinino em receptora equina após interrupção da administração de progesterona aos 120 dias de gestação
}

Lucas Emanuel Ferreira Canuto', Frederico Ozanam Papa, Jose Antonio Dell'Aqua Jr, Lucas Troncarelli Rodrigues, Felipe Erison Medrado Rocha de Sousa, Marco Antonio Alvarenga, Patricia de Mello Papa, Sidnei Nunes de Oliveira, Endrigo Adonis Braga de Araujo, Luis Fernando Mercês Chaves Silva, João Alexandre Matos Carneiro

Faculdade de Medicina Veterinária e Zootecnia, Universidade Estadual Paulista (UNESP), Botucatu, SP, Brasil

*Autor correspondente

e-mail: chiacchios@fmvz.unesp.br

\section{Resumo}

De uma forma geral a fisiologia reprodutiva dos equídeos é semelhante, no entanto diferenças específicas entre os equinos e os asininos são evidentes, como o período de gestação, número de cromossomos e a gonadotrofina coriônica asinina (dCG). Biotecnologias empregadas são as mesmas e geralmente são utilizadas entre as espécies, como inseminação artificial de éguas com sêmen de jumento e transferência de embrião asinino para receptora equina. Nos jumentos, a transferência de embriões tem apresentado baixas taxas de gestação, principalmente em transferência intraespecífica, a baixa viabilidade dos embriões asininos, qualidade das receptoras, nível de sincronia entre doadora e receptoras, liberação de PGF2 $\alpha$ com consequente luteólise, motivado pela difícil manipulação da cérvix no momento da passagem transcervical. A principal alternativa para esse problema é a transferência do embrião asinino para uma receptora equina, contudo, na inovolução interespecífica tem sido observado que éguas gestantes com embriões asininos e muares apresentam maiores perdas embrionárias comparadas às éguas com embrião equino. Possivelmente essas perdas embrionárias e aborto do feto estão diretamente relacionadas a concentrações médias semanais de progesterona e eCG, significativamente menores nas gestantes de embrião interespecífico quando comparado com embrião equino. 0 desenvolvimento de concepto interespecífico causa acentuadas diferenças na taxa de desenvolvimento do ambiente uterino, tamanho, duração e atividade endócrina dos cálices endometriais. Essas estruturas únicas para os equídeos desenvolvem-se como uma série de protuberâncias dispostas em círculo em torno do corno gravídico e estão presentes entre 40 e 120 dias de gestação. Cada cálice endometrial consiste em uma massa densamente embalada de células trofoblásticas epiteliais e produz gonadotrofina coriônica equina (eCG), estimulando o desenvolvimento de corpos lúteos acessórios que ajudam a manter a gestação. No asinino é a dCG que apresenta uma atividade mais relacionada com a função de LH do que de FSH, ao contrário da eCG. Apesar disso, o concepto continua a se desenvolver 
até cerca de 60-65 dias, mas em 80\% dos casos sem a interdigitação normal de vilosidades alantocoriônicas com o endométrio, acompanhado por um afluxo de leucócitos em toda a área do endométrio, causando com isso uma resposta citotóxica mediada por células maternas, podendo causar aborto entre 80 e 100 dias de gestação. Os demais que chegam ao nascimento estão desnutridos devido ao comprometimento das trocas placentárias, uma vez que a receptora não receba suplementação hormonal ou tratamento imunológico. Uma égua srd, com aproximadamente 6 anos, foi inovulada com embrião asinino de 8 dias e recebeu o mesmo manejo e reposição hormonal (Altrengest ${ }^{\circledR}, 5 \mathrm{~mL}$ IM a cada sete dias) que as demais receptoras de embrião equino. Com essa suplementação de progesterona, manteve níveis normais quando comparada às outras éguas. Aos 120 dias, interrompeu-se a suplementação hormonal como procedimento padrão dos programas de transferência de embrião em equinos, quando se utiliza a progesterona exógena. Após 2 dias, na avaliação convencional da gestação com ultrassonografia, a placenta e demais estruturas estavam totalmente desprendidas da parede uterina; em razão disso, não houve qualquer sinal de viabilidade fetal. Após 24 horas houve a expulsão do feto, o qual foi levado ao HV da UNESP-Botucatu. Chegando ao Departamento de Reprodução Animal, realizou-se a investigação e, posteriormente, na Área de Patologia Veterinária, tanto o feto quanto a placenta passaram por avaliação detalhada. Frente à avaliação anatomopatológica, somada às informações obstétricas e à dosagem de progesterona nos dias $0,15,30,60$, 90, e 120 de gestação, concluise que o aborto foi causado pela interrupção do tratamento com Altrengest ${ }^{\circledR}$, não havendo a substituição da progesterona pelos envoltórios fetais devido à incompatibilidade entre as espécies.

Palavras-chave: Transferência de embrião. Equus asinus. Progestágeno. 